\title{
Variation of Water Quality of Four Micro Watersheds Outlets in Upstream of Mahaweli River during Maha Cropping Season
}

\author{
N.S. Abeysingha ${ }^{1 *}$, M.I. Madusanka ${ }^{1}$, B. Rotawewa ${ }^{2}$ and N. Gunasena ${ }^{2}$ \\ ${ }^{I}$ Department of Agricultural Engineering and Soil Science, Faculty of Agriculture, \\ Rajarata University of Sri Lanka, Anuradhapura, Sri Lanka \\ ${ }^{2}$ Food and Agriculture Organisation of the United Nations, Colombo 07, Sri Lanka
}

Date Received: 11-07-2019

Date Accepted: 22-12-2019

\begin{abstract}
Non-point source, agriculture based pollutants have been identified as one of the main cause for water pollution in Sri Lanka. Naranhinna, Pambadeniya Kappeti-Ela, and Rajamale micro watersheds located in the Kandy district have been identified by the project on Rehabilitation of degraded agricultural lands in the Central Highlands implemented by Food and Agricultural Organisation (FAO) to rehabilitate through watershed management plan. This study assessed the baseline water quality status of these micro watersheds by obtaining water samples at the outlet of each watersheds during the Maha cropping seasons 2018/2019. Three replicates water samples from each outlets were collected six times and analysed for EC , pH, TDS, $\mathrm{CO}_{3}{ }^{2-}, \mathrm{HCO}_{3}{ }^{-}, \mathrm{NO}_{3}{ }^{-}, \mathrm{NH}_{4}{ }^{+}$, available $\mathrm{P}$, total $\mathrm{K}, \mathrm{Na}, \mathrm{Ca}, \mathrm{Mg}, \mathrm{Fe}, \mathrm{Al}, \mathrm{As}, \mathrm{Cd}, \mathrm{Cr}, \mathrm{Mn}$, and $\mathrm{Pb}$ using standard methods. Most of the tested drinking water quality parameters in all four micro watersheds were within the permissible limits of World Health Organisation (WHO) standard except Fe and $\mathrm{NH}_{4}{ }^{+}$. Observed Fe contents exceeded the WHO limits $(0.3 \mathrm{mg} / \mathrm{L})$ of all watersheds and was in the range of 1.2$1.5 \mathrm{mg} / \mathrm{L}$. Concentration of $\mathrm{NH}^{+}$at Kappeti Ela, Rajamale, and Pambadeniya was in the range of 0.5 to $0.7 \mathrm{mg} / \mathrm{L}$ which exceeded the WHO standard $(0.5 \mathrm{mg} / \mathrm{L})$. Using the tested parameters, study calculated drinking water quality index (DWQI) and also irrigation water quality index (IWQI) for all investigated micro watersheds for each of the sampling date. According to the guideline, mean DWQI (19 to 48.1) graded the water of all micro watersheds as excellent while IWQI (8.7-9.2) characterised them as excellent for any crops during the study period.
\end{abstract}

Keywords: Drinking water quality, irrigation water quality, Mahaweli River, micro-watersheds

\section{Introduction}

Rivers in Sri Lanka can be considered as life blood of its economy and development as it plays a major role in irrigation, hydro power generation, municipal water supply, and also there are valuable freshwater ecosystems in association with the rivers in the country. Discharge of pollutants without proper treatments to a river system from domestic sources, storm water discharges, industrial wastewaters, agricultural runoff and the other sources can have short term and long term detrimental effects on the quality of a river system (Singh, 2007). The Mahaweli River is the longest river in Sri Lanka which flows for $335 \mathrm{~km}$ covering about 16\% of land area of Sri Lanka (Withanachchi et al., 2014). It contributes to one seventh of Sri Lankas' total runoff (Hewawasam, 2010) and a succession of multipurpose reservoirs have been built to capture the runoff under Mahaweli Development Programme. Upstream Mahaweli is the main water production area of the river and water reaching from these area is fast getting polluted due to unfavorable human activities.

*Correspondence: nabeysingha@gmail.com

Tel: +94714444849

ISSN 2235-9370 Print/ISSN 2235-9362 Online @University of Sri Jayewardenepura 

It is identified that the use of excessive amount of synthetic inorganic fertilizer, pesticides on crops and grasslands; raring of farm animals, especially cattle in the river basin, waste disposal to river, and soil erosion in cultivated lands and construction sites in the river basin as ways of water pollution (Dissanayake and Weerasooriya, 1986). Land degradation especially from soil erosion has been identified as a major issue in upper Mahaweli area (Hewawasam, 2010). It is noted that Mahaweli River receives large amount of harmful materials from highly polluted canals, side streams or drains (Dissanayake and Weerasooriya, 1986). River water quality also varies over both space and time (Ai et al., 2015). Upstream Mahaweli water quality may be different from those of downstream Mahaweli water.

Four micro watersheds Naranhinna, Kappeti Ela, Rajamale, and Pambadeniya located in upper Mahaweli area of Kandy district have been selected to rehabilitate by the UN FAO funded project. Monitoring water quality is crucial to understand watershed health and for establishing appropriate watershed management plan (Charalampous et al., 2015). This rehabilitation project sought to know the variation of surface water quality of these micro watersheds before starting their land rehabilitation programmes. Therefore, this study focused to investigate the status of water quality in four micro watersheds during the Maha cropping season (September to March 2018/19), and also probe into the reasons for the variation.

\section{Materials and Methods}

\subsection{Study area}

This study was carried out in four micro-watersheds, Naranhinna, Kappetiya Ela, Rajamale, and Pambadeniya located in Deltota divisional secretariat (DS) division and Doluwa divisional secretariat division in Kandy district. Figure 1 shows the spatial distribution of these micro watersheds in DS divisions. These watersheds were delineated taking the water quality monitoring places as outlets using ArcGIS 10.2 software. Moreover, Table 1 summarises the land use and land cover, area extent, number of farmers and some locational characteristics of four micro watersheds.

Naranhinna watershed situated in Gonangoda, Pattiyagama, and Gabadagama Grama Niladari (GN) divisions of Deltota divisional secretary division while $95 \%$ of micro watershed extent located in Gonangoda GN division. As shown in Table 1, Naranhinna watershed extends 149 ha and elevation ranges between $840 \mathrm{~m}$ to $1,520 \mathrm{~m}$ above $\mathrm{msl}$, located in the eastern slope of central highlands.

Keppitiya Ela micro watershed with an extent of 203 ha is in three villages namely Gurukele, Nawa Gurukelle and Lagumdeniya that located in. Gurukele GN division of Doluwa divisional secretariat division. Nawa Gurukelle villages covers major part of the micro watershed. The elevation of Keppitiya Ela micro watershed ranges between 590-870 m above msl and comparatively large extent of agricultural lands are occupied in the watershed. Rajamale micro-watershed is the largest micro watershed extending 206 ha is located in the Gurukele and Panwilathanna GN divisions of Doluwa divisional Secretariat Division. Its elevation ranges between 600-890 m above msl. The smallest micro watershed selected for the study is Pambadeniya micro-watershed with area of 83 ha which is located in Pambadeniya and Panwilathanna GN divisions of Doluwa divisional secretariat division and Pambadeniya GN division covers $85 \%$ of this micro watershed.

In addition, baseline survey of the project identified that Naranhinna watershed is a part of Gurugal Oya sub watershed of Mahaweli River. Keppitiya Ela and Rajamale micro watersheds are located in the Nillamba sub-watershed while Pambadeniya micro watershed is located in Atabageoya subwatershed of Mahaweli River basin. 
Table 1: Land use and land cover, and important locational characteristics of four micro watersheds.

\begin{tabular}{lcccc}
\hline Micro watershed name & Naranhinna & KeppetiyaEla & Rajamale & Pabadeniya, \\
\hline DS Division & $\begin{array}{c}\text { Delthota } \\
\text { Gonangoda,Pattiyagama } \\
\text { Gabadagama North }\end{array}$ & $\begin{array}{c}\text { Doluwa } \\
\text { Gurukelle }\end{array}$ & $\begin{array}{c}\text { Doluwa } \\
\text { Gurukelle, } \\
\text { Panvilathenna }\end{array}$ & $\begin{array}{c}\text { Poluwa } \\
\text { Panvileniya }\end{array}$ \\
Number of farmers & 138 & 71 & 307 & 135 \\
Micro watershed extent (ha) & 149 & 203 & 206 & 83 \\
Agricultural land extent (ha) & 48 & 143 & 138 & 59 \\
Tea (ha) & 33 & 73 & 89 & 30 \\
Home garden (ha) & 13 & 11 & 11 & 9 \\
Mixed crops (ha) & 0 & 57 & 9 & 19 \\
Paddy (ha) & 0 & 2 & 1 & 0 \\
Vegetable (ha) & 2 & 0 & 1 & 0 \\
Abandoned agricultural lands (ha) & 64 & 45 & 46 & 0 \\
Reservations (ha) & 3 & 1 & 8 & 15 \\
Forest (ha) & 25 & 0 & 0 & 0 \\
Pinus plantation (ha) & 6 & 0 & 26 & 0 \\
Poultry farm (ha) & 0 & 6 & 1 & 1 \\
Other (cemetery, playground etc.) (ha) & 3 & & & 0 \\
\hline
\end{tabular}

\subsection{Sample collection}

Samples were collected from the outlets of watersheds in three week interval during Maha cropping season. Three samples/ replicates from each outlets were collected six times from September 2018 to March 2019. Sampling points were permanently selected before starting the work and GPS locations of selected points were recorded. Water samples were collected in clean plastic sampling bottles in the early hours of the day. Sampling bottles were previously rinsed with detergent, tap water, and then distilled water. Collection of water samples was done by first rinsing the bottles three times with the water taken from watershed outlet before collection. Collected water samples were immediately covered, labelled and brought to the lab for analysis.

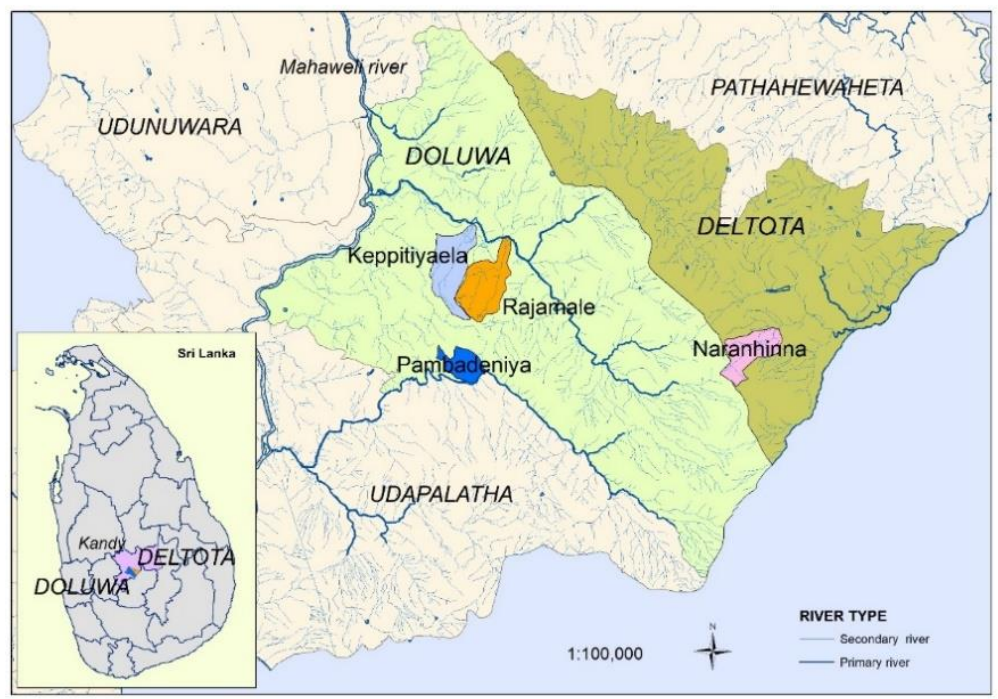

Figure 1. Geographical locations of four Micro watersheds Naranhinna, KappetiEla, Rajamale, and Pambadeniya. 


\subsection{Analysis of water samples}

The water samples were analysed for $\mathrm{pH}, \mathrm{EC}, \mathrm{TDS}, \mathrm{NH}_{4}{ }^{+}-\mathrm{N}, \mathrm{NO}_{3}^{-}-\mathrm{N}$, Available $\mathrm{P}$, Total K, Na, $\mathrm{Ca}, \mathrm{Mg}, \mathrm{Fe}, \mathrm{Al}, \mathrm{As}, \mathrm{Cd}, \mathrm{Pb}$, and $\mathrm{Hg}$. Water temperature, $\mathrm{pH}, \mathrm{EC}$, TDS were measured immediately using the multi-parameter analyser $\left(\mathrm{HATCH}\right.$, Sension 156). Other parameters such as $\mathrm{NH}_{4}^{+}-\mathrm{N}, \mathrm{NO}_{3}^{-}-\mathrm{N}$, Available $\mathrm{P}$, Total $\mathrm{K}, \mathrm{Na}, \mathrm{Ca}, \mathrm{Mg}, \mathrm{Fe}, \mathrm{Al}, \mathrm{As}, \mathrm{Cd}, \mathrm{Pb}, \mathrm{Hg}$ were determined in the laboratory by using standard laboratory methods. $\mathrm{NH}_{4}{ }^{+}-\mathrm{N}$ content was determined by UV-visible spectrophotometer with $4500 \mathrm{NH}_{3} \mathrm{~F}$ Phenate method (Solorzano, 1969). $\mathrm{NO}_{3}^{-}-\mathrm{N}$ content of water samples were tested by UVvisible spectrophotometer with salicylic acid method (Cataldo et al., 1975). Available P content of water samples was determined by UV-visible spectrophotometer with ascorbic acid method (Olsen et al., 1954). Total K, Na, Ca, Mg, Fe, Al, As, Cd and Pb contents were measured by ICP-OES following the method of Martin et al. (1994).

In addition, Sodium Percentage (SP), Sodium Adsorption Ratio (SAR) and Residual Sodium Carbonate (RSC), Kelly's ratio (KR), and Magnesium Hazard (MH) were calculated to test the suitability of water especially for irrigation. Sodium percentage $(\mathrm{Na} \%)$ was calculated using the following formula. All ionic concentrations in the equation 1 are expressed in meq/L.

$\mathrm{Na}(\%)=\left(\frac{\mathrm{Na}^{+}+\mathrm{K}^{+}}{\mathrm{Ca}^{2+}+\mathrm{Mg}^{2+}+\mathrm{K}^{+}}\right) \times 100$

SAR was calculated from the ratio of sodium to calcium and magnesium (Richards 1954). All ionic concentrations in the equation 2 are expressed in meq/L.

$\mathrm{SAR}=\frac{\mathrm{Na}^{+}}{\sqrt{\frac{\mathrm{Ca}^{2+}+\mathrm{Mg}^{2+}}{2}}}$

Residual Sodium Carbonate (RSC) index was calculated from the difference of total carbonate and bicarbonate with total calcium and magnesium (Ragunath, 1987). All ionic concentrations in the equation 3 are expressed in meq/L.

$\mathrm{RSC}$ index $=\left[\mathrm{HCO}_{3}^{-}+\mathrm{CO}_{3}^{2-}\right]-\left[\mathrm{Ca}^{2+}+\mathrm{Mg}^{2+}\right]$

The Kelly's ratio was measured using the expression (Kelly, 1963). All ionic concentrations in the equation 4 are expressed in meq/L.

$\mathrm{KR}=\frac{\mathrm{Na}^{+}}{\mathrm{Ca}^{2+}+\mathrm{Mg}^{2+}}$

The Magnesium hazard (MH) was calculated using the equation 5 (Szabolcs and Darab, 1964).

$\mathrm{MH}=\left(\frac{\mathrm{Mg}^{+}}{\mathrm{Ca}^{2+}+\mathrm{Mg}^{2+}}\right) \times 100$

Moreover, Irrigation Water Quality Index (IWQI) and Drinking Water Quality Index (DWQI) were also calculated following the equation 4 (Stambuk, 1999).

$\mathrm{DWQI}=\Sigma \mathrm{Si}_{\mathrm{i}}-\mathrm{n}$ 
Where:

$$
\begin{aligned}
& \mathrm{n}=\text { number of parameters } \\
& \mathrm{Si}_{\mathrm{i}}=\text { the sub index of } \mathrm{n}^{\text {th }} \text { parameter }
\end{aligned}
$$

$$
\begin{aligned}
& \mathrm{Si}_{\mathrm{i}}=\mathrm{W}_{\mathrm{i}} \times \mathrm{q}_{\mathrm{i}} \\
& \mathrm{q}_{\mathrm{i}}=\frac{\mathrm{C}_{\mathrm{i}}}{\mathrm{S}_{\mathrm{i}}} \times 100
\end{aligned}
$$

Where:

$$
\begin{aligned}
& \mathrm{C}_{\mathrm{i}}=\text { concentration of each chemical parameter in each water sample in } \mathrm{mg} / \mathrm{L} \\
& \mathrm{S}_{\mathrm{i}}=\text { drinking water quality standard for each chemical parameter in } \mathrm{mg} / \mathrm{L}
\end{aligned}
$$

$\mathrm{W}_{\mathrm{i}}=\frac{\mathrm{W}_{\mathrm{x}}}{\sum_{\mathrm{i}=1}^{\mathrm{n}} \mathrm{W}_{\mathrm{x}}}$

Where:

$$
\mathrm{W}_{\mathrm{x}}=\text { relative weight }
$$

Descriptive statistics such as mean, max and min and standard deviation were calculated for the parameters tested for each points and considered them as the water quality status of micro watersheds.

\section{Results and Discussion}

This chapter first discusses the mean status of the water quality data of the outlet of the four micro watersheds and then compare the tested water quality parameters with the standards of FAO irrigation and WHO drinking water quality. Since the comparison of each parameter on the standards doesn't give overall idea about the suitability of water for irrigation or drinking, this study discusses the overall mean IWQI and DWQI of waters of each micro watersheds also.

\subsection{Mean status of the water quality of four micro watershed outlets}

As physical and physicochemical parameters $\mathrm{pH}$, turbidity and electrical conductivity (EC) was tested and their mean values of the six times sampling are shown in Table 2. $\mathrm{pH}$ of the four watersheds water during Maha cropping season ranged from slightly acidic (6.88) to slightly basic (7.14).

Table 2: Variation of physical and physicochemical water quality parameters of four micro-watersheds.

\begin{tabular}{lccc}
\hline Watersheds & $\mathrm{pH}$ & Turbidity (NTU) & $\begin{array}{c}\text { Electrical Conductivity } \\
(\mathrm{EC})(\mu \mathrm{S} / \mathrm{cm})\end{array}$ \\
\hline Naranhinna & 7.14 & 3.95 & 38.35 \\
KappetiEla & 6.86 & 4.88 & 39.20 \\
Rajamale & 6.89 & 5.01 & 28.11 \\
Pambadeniya & 6.88 & 4.56 & 36.05 \\
\hline WHO Drinking water quality standards & $6.5-8.5$ & 5.00 & 750 \\
FAO Irrigation water quality standards & $6.5-8.5$ & - & 700 \\
\hline
\end{tabular}

Turbidity is a measure of the degree to which the water loses its transparency due to the presence of suspended particle and it shows the relative clarity of the water. Mean turbidity of the micro watersheds outlets varied from 3.95 to 5.01 NTU during the Maha cropping seasons 2018/19. EC represents the total ionised constitutes of water which is a measure of dissolved salts in water. During the sampling time mean EC was in the ranged from 28.11 to $39.2 \mu \mathrm{S} / \mathrm{cm}$ (Table 2) in all micro watersheds. 
The $\mathrm{NO}_{3}-\mathrm{N}, \mathrm{NH}_{4}-\mathrm{N}$ and $\mathrm{PO}_{4}-\mathrm{P}$ are plant nutrients and their concentration in water indicates eutrophication status of water bodies. The mean $\mathrm{NO}_{3}-\mathrm{N}$ concentrations of four micro watersheds varies from 3.31 to 6.47 in water (Table 3) while mean $\mathrm{NH}_{4}-\mathrm{N}$ concentration was in the range of 0.42 to 0.75 ppm.

Table 3: Variation of chemical water quality parameters of four micro-watersheds.

\begin{tabular}{|c|c|c|c|c|c|c|}
\hline Watersheds & $\begin{array}{c}\mathrm{NH}_{4--\mathrm{N}} \\
(\mathrm{ppm})\end{array}$ & $\begin{array}{c}\mathrm{NO}_{3--\mathrm{N}} \\
(\mathrm{ppm})\end{array}$ & $\begin{array}{r}\mathrm{PO}_{4--} \mathrm{P} \\
(\mathrm{ppm})\end{array}$ & $\begin{array}{l}\mathrm{HCO}_{3}^{-} \\
(\mathrm{ppm})\end{array}$ & $\begin{array}{l}\mathrm{CO}_{3}^{-2} \\
(\mathrm{ppm})\end{array}$ & $\begin{array}{l}\text { TDS } \\
(\mathrm{ppm})\end{array}$ \\
\hline Naranhinna & 0.42 & 3.74 & 0.02 & 129.67 & 5.83 & 18.13 \\
\hline KappetiEla & 0.51 & 3.31 & 0.01 & 90.67 & 3.33 & 18.38 \\
\hline Rajamale & 0.53 & 6.47 & 0.01 & 90.33 & 6.67 & 13.15 \\
\hline Pambadeniya & 0.75 & 4.40 & 0.01 & 120.17 & 5.83 & 16.88 \\
\hline $\begin{array}{l}\text { WHO Drinking water } \\
\text { quality standards }\end{array}$ & 0.5 & 50 & 5 & 200 & 100 & 300 \\
\hline $\begin{array}{l}\text { FAO Irrigation water } \\
\text { quality standards }\end{array}$ & $0-5$ & 05 & $0-2$ & 610 & $0-30$ & $\begin{array}{l}450- \\
2000\end{array}$ \\
\hline
\end{tabular}

Considering the metal tested, Ca was recorded the highest and the lowest was Zn (Table 4). During the study period, total iron concentration in all four micro watersheds water ranged from 1.23 to $1.52 \mathrm{mg} / \mathrm{L}$. Pb was observed comparatively higher concentration as a heavy metal and was in the range of 1.94 to $1.46 \mathrm{ppb}$. As was observed only in Naranhinna micro watershed outlet while Cr was observed approximately same concentration $(0.01 \mathrm{ppm})$ in all micro watershed outlets. The Al concentration of all four micro watersheds varied from 0.00 to $0.05 \mathrm{mg} / \mathrm{L}$ (Table 4).

Table 4: Variation of Metallic water quality parameters of four-micro watershed.

\begin{tabular}{lcccccc}
\hline & Naranhinna & KappetiEla & Rajamale & Pambadeniya & $\begin{array}{c}\text { WHO Drinking } \\
\text { water quality } \\
\text { standards }\end{array}$ & $\begin{array}{c}\text { FAO Irrigation } \\
\text { water quality } \\
\text { standards }\end{array}$ \\
\hline $\mathrm{Na}(\mathrm{ppm})$ & 0.55 & 0.97 & 0.7 & 0.68 & 200 & $0-920$ \\
$\mathrm{Mg}(\mathrm{ppm})$ & 1.61 & 1.34 & 0.79 & 1.59 & 30 & $0-60.75$ \\
$\mathrm{Ca}(\mathrm{ppm})$ & 3.96 & 3.33 & 2.04 & 4.88 & 75 & $0-400$ \\
$\mathrm{Cd}(\mathrm{ppb})$ & 0.06 & 0.04 & 0.04 & 0.04 & 3.0 & 0.01 \\
$\mathrm{~Pb}(\mathrm{ppb})$ & 1.46 & 1.86 & 1.89 & 1.94 & 10 & 5.0 \\
$\mathrm{As}(\mathrm{ppb})$ & 4.8 & 0.0 & 0.0 & 0.0 & 10 & 0.1 \\
$\mathrm{Al}(\mathrm{ppm})$ & 0.05 & 0.0 & 0.01 & 0.02 & 0.2 & 5.0 \\
$\mathrm{Cr}(\mathrm{ppb})$ & 0.01 & 0.01 & 0.01 & 0.01 & 50 & 5.0 \\
$\mathrm{Fe}(\mathrm{ppm})$ & 1.23 & 1.47 & 1.36 & 1.52 & 0.3 & 0.2 \\
$\mathrm{Mn} \mathrm{ppm})$ & 0.02 & 0.02 & 0.02 & 0.02 & 0.1 & 2.0 \\
$\mathrm{Zn}(\mathrm{ppm})$ & 0.0 & 0.0 & 0.0 & 0.0 & 2.0 & \\
\hline
\end{tabular}

\subsection{Variation of mean water quality parameters with the FAO and WHO guidelines}

The $\mathrm{pH}$ values recorded in watersheds water were within the standard range of irrigation and drinking water quality standard of FAO and WHO respectively. Considering the mean EC, water can be used for drinking and irrigation for any crops without any restriction when compared to WHO drinking and FAO irrigation water quality guidelines.

Turbidity of water of all most all micro watersheds were within the WHO permissible level except at the outlet of Rajamale watershed (Table 2). Turbidity was little higher at the Rajamale watershed 
probably due to suspended soil particles by soil erosion at the watershed. FAO Irrigation water quality standards doesn't provide a critical level for turbidity. However, high level of turbidity can affect the performance of the irrigation facility, and can lower the hydraulic conductivity of the soil and in turn pollute the soil surface through surface flow. Therefore Spain recommends a level lower than 10 NTU for vegetables (Jeong et al., 2016). However, in terms of turbidity, the water of all micro watersheds during the study period is suitable for irrigation.

According to FAO guidelines, sensitive crops may be affected by nitrogen $\left(\mathrm{NO}_{3}-\mathrm{N}\right)$ concentrations above $5 \mathrm{mg} / \mathrm{l}$ (Table 3). The highest value of $\mathrm{NO}_{3}-\mathrm{N}$ is recorded at Rajamale watershed outlet and long term application of water of Rajamale watershed may be affected to nitrogen sensitive crops. This water is however suitable for drinking when compared to WHO guidelines of $\mathrm{NO}_{3}-\mathrm{N}$. Water status of mean $\mathrm{NH}_{4}$ $\mathrm{N}$ concentration, water of three watersheds except Naranhinna is unsuitable for drinking (Table 3). $\mathrm{NH}_{4}-\mathrm{N}$ is an indicator of the breakdown of organic N (Kanownik et al., 2019). Hence, organic nitrogen sources of three micro watersheds may be rearing of cattle and the use of organic fertilizers etc., and natural organic matter decomposition. $\mathrm{PO}_{4}-\mathrm{P}, \mathrm{HCO}_{3}{ }^{-}$and TDS concentrations were with the permissible levels of irrigation and drinking water quality guidelines of FAO and WHO respectively.

Considering the metal tested, $\mathrm{Na}, \mathrm{Mg}, \mathrm{Ca}, \mathrm{Mn}, \mathrm{Al}, \mathrm{Cr}$ and $\mathrm{Zn}$ concentration of all the micro watersheds water were with the permissible levels of WHO and FAO guidelines (Table 4). The incidence of cognitive impairments, especially in children, and cancers of all sorts are links to toxicants such as $\mathrm{Hg}$, $\mathrm{Pb}$, As, and Cd (Obiri et al., 2010). In addition, various studies shows that As, Cd are causes for the chronic kidney disease of unknown etiology that prevailed mainly in dry zone area of Sri Lanka (Abeysingha et al., 2018a). However, tested mean concentration of $\mathrm{As}, \mathrm{Cd}$ and $\mathrm{Pb}$ were within the permissible levels of all four micro watersheds waters during Maha cropping season 2018/19. Water quality study done by Dissanayake and Weerasooriya (1986) showed lower concentration of $\mathrm{Pb}$ (1 to 5 $\mathrm{ppb})$ and $\mathrm{Cd}$ (1 to $2 \mathrm{ppb})$ in entire Mahaweli water.

Fe content of water of all micro watersheds exceeded the WHO drinking water quality limit $(0.3$ $\mathrm{mg} / \mathrm{L})$ of 2004. However, these values did not exceed the concentration for irrigation which is $5 \mathrm{mg} / \mathrm{L}$ (FAO, 1985). High concentrations of Fe are attributable to dissimilarly iron-reduction of Fe(III)-oxide minerals, which is coupled to the oxidation and mineralization of labile organic carbon (Borrok et al., 2018). Dissanayake and Weerasooriya (1986) also observed total Fe content in Mahaweli River in the range of 0.013 to $4.7 \mathrm{mg} / \mathrm{L}$. The $\mathrm{Al}$ concentration of all four micro watersheds were with the permissible levels for drinking and irrigation.

Table 5. Variation of derived water quality parameters of four micro-watersheds.

\begin{tabular}{lccccc}
\hline Watersheds & SAR & RSC & SP \% & KR & MH \\
\hline Naranhinna & 0.18 & 1.99 & 28.65 & 0.25 & 40.34 \\
KappetiEla & 0.34 & 1.88 & 35.81 & 0.46 & 40.00 \\
Rajamale & 0.29 & 1.53 & 43.16 & 0.70 & 40.34 \\
Pambadeniya & 0.25 & 1.79 & 12.79 & 0.36 & 38.85 \\
Suitable limit for irrigation (FAO) & 18 & 2.5 & 60 & 1 & 50 \\
\hline
\end{tabular}

SAR, RSC, SP\%, KR and MH in water samples are generally interpreted for the assessment of the suitability of irrigation water (Brindha and Kavitha, 2015; Abeysingha et al., 2018b). As shown in Table 5 , average derived water quality Parameters of all four micro watersheds were within the permissible critical limit of irrigation water quality of FAO. Therefore, the water of these four micro watersheds can be used for any crops and soil without detrimental effects. 


\subsection{Water quality indexes}

Drinking and irrigation water quality indexes were calculated using analysed results and standard values of FAO and WHO and results are shown in Table 6. According to Table 6, the water of all four micro watersheds can be graded as excellent in terms of mean DWQI and it varied from 19.0 to 48.1. The maximum values of DWQI reached 97 at Pambadeniya micro watershed which is also good according to the Stambuk (1999). Considering mean IWQI (8.7-9.2) of tested watersheds, the water can be characterised as excellent for any crops during the study period. However, this analysis did not consider water quality parameters such as micro biological status of water due to limited funding for the study. In addition, high water pollution may be present most frequently during low flow dry season due to lower dilution effect (David et al., 2013). Therefore, it is suggested to monitor the water quality status of these four micro watersheds during low rainy, Yala cropping season along with the streamflow to further understand entire behavior of these four micro watersheds in relation to water quality.

Table 6: Variation of irrigation and drinking water quality indexes.

\begin{tabular}{lcccccc}
\hline & \multicolumn{3}{c}{ IWQI } & & \multicolumn{3}{c}{ DWQI } \\
\hline Watersheds & Min & Max & Mean & Min & Max & Mean \\
\hline Naranhinna & 7.9 & 9.9 & 8.7 & 29.2 & 67.4 & 48.1 \\
KappetiEla & 7.8 & 11.3 & 9.2 & 28.0 & 38.1 & 34.0 \\
Rajamale & 7.3 & 12.6 & 9.0 & 11.7 & 25.9 & 19.0 \\
Pambadeniya & 4.5 & 10.0 & 7.1 & 31.5 & 97.0 & 45.1 \\
\hline
\end{tabular}

Note: 0-50:Excellent, 51-100:Good, 101-200:Poor, 201-300:very poor, >300:unsuitable

\section{Conclusions}

The results of this study showed that the most of the tested drinking water quality parameters in all four micro watersheds were within the permissible limits of WHO standards but Fe and $\mathrm{NH}_{4}^{+} \mathrm{N}$ concentrations exceed the permissible level. Observed Fe content of all watersheds was in the range of 1.2-1.5 mg/L. Concentration of $\mathrm{NH}^{+}$at Kappeti Ela, Rajamale, and Pambadeniya was in the range of 0.5 to $0.7 \mathrm{mg} / \mathrm{L}$ which exceeded the WHO standard $(0.5 \mathrm{mg} / \mathrm{L})$. However, the water of all four micro watersheds can be graded as excellent in terms of DWQI and it varied from 19 to 48.1. Considering mean IWQI (8.7-9.2) of tested watersheds, the water can also be characterized as excellent for any crops during the study period.

\section{References}

Abeysingha, N.S., Dassanayake, K.B. and Weerarathna, C.S., 2018a. Will restoration of ecological functions of tank cascade system contribute to reduce CKDu in Sri Lanka? A Review. Journal of Environment Management and Sustainable Development, 7:60-81.

Abeysingha, N.S., Silva, D.S.M.D. and Duminda, D.M.S., 2018b. Hydro chemical assessment of agrowell water for irrigation in Thalawa Block in Mahaweli system-H in Anuradhapura, Sri Lanka. The Journal of Agricultural Sciences-Sri Lanka, 13:186-199.

Ai L., Shi Z.H., Yin W. and Huang X., 2015. Spatial and seasonal patterns in stream water contamination across mountainous watersheds: Linkage with landscape characteristics. Journal of Hydrology, 523:398-408.

Brindha, K. and Kavitha, R., 2015. Hydrochemical assessment of surface water and groundwater quality along Uyyakondan channel, south India. Environmental Earth Science, 73:5383-5393.

Borrok, D.M., Lenz, R.M., Jennings, J.E., Gentry, M.L., Steensma, J. and Vinson, D.S., 2018. The origins of high concentrations of iron, sodium, bicarbonate, and arsenic in the Lower Mississippi River alluvial aquifer. Applied Geochemistry, 98:383-392. 
Charalampous, N., Kindou, A., Vlastos, D., Tsarpali, V., Antonopoulou, M., Konstantinou, I. and Dailianis, S., 2015. A multidisciplinary assessment of river surface water quality in areas heavily influenced by human activities. Achieves of Environmental Contamination and Toxicology, 69:208-222.

David, A., Tournoud, M.G., Perrin, J.L., Rosain, D., Rodier, C., Salles, C., Bancon-Montigny, C. and Picot, B., 2013. Spatial and temporal trends in water quality in a mediterranean temporary river impacted by sewage effluents. Environmental Monitoring and Assessment, 185:2517-2534.

Dissanayake, C.B. and Weerasooriya, S.V.R., 1986. The environmental chemistry of mahaweli river, Sri Lanka. International Journal of Environmental Studies, 28:207-223.

Hewawasam, T., 2010. Effect of land use in the upper Mahaweli catchment area on erosion, landslides and siltation in hydropower reservoirs of Sri Lanka. Journal of the National Science Foundation of Sri Lanka, 38:3-14.

Jeong, H., Kim, H. and Jang T., 2016. Irrigation water quality standards for indirect wastewater reuse in agriculture: A contribution toward sustainable wastewater reuse in South Korea. Water, 8:169.

Kelly, W.P., 1963. Use of saline irrigation water, Soil Science. 95:355-39.

Kanownik, W., Policht-Latawiec, A. and Fudała, W., 2019. Nutrient pollutants in surface water-assessing trends in drinking water resource quality for a regional city in Central Europe. Sustainability MDPI, 11:1-15.

Martin, T.D., Brockhoff, C.A. and Creed J.T., 1994. EMMC methods work group-Method 200.7, Determination of metals and trace elements in water and wastes by inductively coupled plasmaatomic emission spectrometry. Revision 4.4, U. S. Environmental Protection Agency, Cincinnati, Ohio.

Obiri, S., Dodoo, D.K., Essumang, D.K. and Armah, F.A., 2010. Cancer and non-cancer risk assessment from exposure to arsenic, copper, and cadmium in borehole, tap, and surface water in the Obuasi municipality. Ghana, Human and Ecological Risk Assessment, 22:651-665.

Ragunath, H.M., 1987. Groundwater. Wiley Eastern Ltd., New Delhi. 563.

Richards, L.A., 1954. Diagnosis and improvement of saline and Alkali soils. USDA handbook, 60.

Stambuk, G.N., 1999. Water quality Evaluation by Index in Dalmatia. Water Research, 33:3423-3440.

Szabolcs, I. and Darab, C., 1964. The influence of irrigation water of high sodium carbonate content of soils, 2:802-812.

Singh L.B., 2007. River Pollution. 1st ed., APH Publishing, New Delhi. 192.

Withanachchi, S.S., Köpke, S., Withanachchi, C.R., Pathiranage, R. and Ploeger A., 2014. Water Resource Management in Dry Zonal Paddy Cultivation in Mahaweli River Basin, Sri Lanka: An Analysis of Spatial and Temporal Climate Change Impacts and Tradit ional Knowledge. Climate, 2:329-354. 